\title{
SEX STUDIES
}

XI. HERMAPHRODITE BIRDS ${ }^{1}$

ALICE M. BORING AND RAYMOND PEARL

NINE TEXT FIGURES AND NINE PLATES

\section{INTRODUCTION}

Studies IX and $\mathrm{X}$ of this series have dealt with the normal structure of the reproductive organs in the domestic chicken. That matter was undertaken as a preliminary to the study of certain hermaphrodite birds which have come into the possession of the Maine Agricultural Experiment Station. It is only possible to interpret abnormal conditions in the light of and by comparison with the normal. The present study undertakes a description of the external sex characters and internal reproductive structures or these abnormal birds. The general bearing of both normal and abnormal structures in the reproductive systems of the chicken on theories of secondary sex characters will be discussed in still another paper, which has to be delayed for some time as one of the authors (R. P.) has been called by the government to turn his attention to war time problems.

\section{MATERIAL AND METHODS}

The material for this study comprises a large number of birds belongirg to the poultry plant of the Maine Agricultural experiment Station. The work has centered around eight hermaphrodite birds. Five of these birds were bought from Herr Houwink, a well known writer on problems of heredity and evolution in poultry, in Meppel, Holland. They are Drentisch fowls, the common breed of North Holland. He states that "these fowls

${ }^{1}$ Papers from the Biological Laboratory of the Maine Agricultural Experiment Station No. 116. 
are cultivated by inbreeding." In 1909, he started this particular stock with one cock and six hens. From then on, he has inbred them. In the $F_{2}$ generation in 1911 there appeared two hermaphrodites out of 80 birds, and in $F_{3}$ in 1912, there were three more hermaphrodites out of 80 birds. These are the five birds sent to Maine. These were by no means all the birds of the sort which Herr Houwink had produced. When one of the writers (R. P.) visited his breeding plant in Meppel in 1910 there were then on hand a considerable number of these supposed hermaphrodite birds. Herr Houwink was of the opinion, as already stated, that inbreeding was the cause of these abnormalities, but without producing evidence which was conclusive to this effect.

These Holland birds were numbered 1425, 1426, 1427, 1428 and 1429 on the Experiment Station poultry plant, and will go by these numbers in this paper. One of the other three hermaphrodites was a small black bird sent to the Experiment Station by Prof. Horace Atwood of West Virginia. This will be referred to as Atwood's black hermaphrodite. The seventh hermaphrodite appeared in the Station flock of pure Barred Plymouth Rock ancestry. The number of this bird is 1349 . The eighth bird, 1616, was sent from Michigan by Professor Dexter. These eight birds vary in the proportion of male and female in their make-up, both as to external and internal structure, and behavior. It seems clearest to arrange them in a series from the most female at one end to the most male at the other end as the various features of structure and behavior are taken up, using the structure of the prmary sex organs as the basis for this serial arrangement.

This study has been carried a little further and included other birds with abnormal sex behavior, but normal structure. That is, to complete the more female end of the series, we have studied several apparently normal hens that tread other hens. Of these, 1422 was sent from West Virginia by Professor Atwood as a possible hermaphrodite but has behaved normally in Maine. K134 and M408 were two such birds reared at the Station plant and finally killed to study their anatomy and histology. 
To complete the more male end of the series we have studied two guinea-chicken hybrids, one raised on the Maine poultry plant and the other sent in for examination from the country. Their gonads appeared to be testes, but their behavior was indifferent.

This series of birds has been studied from as many aspects as possible. The external secondary sex characters have been observed and many of the birds photographed to show any deviations from the normal. The behavior of the entire series has been carefully watched under various conditions and recorded. The birds were finally killed to study the anatomy and histology of the reproductive organs. The alimentary tract and associated organs were removed and a piece of the back with the entire urogenital system was put in McClendon's fluid (10 per cent formalin, sugar, lime) to fix and harden. Then a careful dissection was made of the urogenital system, and this was photographed. The reproductive organs and ducts were then sectioned and studied histologically. Delafield's haematoxylin and orange $\mathrm{G}$ were used for the general histological condition of the glands. The more special staining methods for studying interstitial cells have been considered in detail in study IX of this series.

\section{EXTERNAL SEX CHARACTERS AND SEX BEHAVIOR}

Secondary sexual characters are very distinct and attain a relatively high degree of development in the domestic fowl. The cock bird is distinguished from the hen in a whole series of obvious respects. Of these the best known and most apparent are; (1) greater body size; (2) different shape of body and carriage; (3) large comb and wattles; (4) presence of spurs; (5) presence of differentiated feathers in hackle, saddle and tail, (6) in some breeds dimorphism in color and pattern. There are many finer differences which can be recognized by the poultry expert.

Presence of testes is supposed to cause the appearance of one set of these characters; presence of ovary, the appearance of the

other. Actually in some ten years study of these characters in 
poultry at the Maine Station it has been found that there is no single one of the so-called male secondary sex characters which has not at some time been seen well developed in an otherwise perfectly normal female. Laying females with spurs, or with large, male-like comb and wattlês, while not common, still appear every year in small numbers amongst the large numbers of birds in the whole flock. Females with male secondary plumage are rarer but still occur. Putting all our experience together we have come finally to the view that there is no distinct secondary sexual character for which the correlation with the primary organ is perfect and unvarying.

Taking a general survey of the external characters of the birds in this study, and taking especially into account the shape of body and body carriage, they would fall into line from most female to most male in the same order as mentioned above,that is, the sum total of external characters, and particularly the body shape and carriage, would correspond roughly to the internal anatomy. They cannot be compared as to body size as they were not all of the same breed nor were they of the same age when killed for anatomical study.

Various female birds in the Station flock, which are normal laying birds at times tread the other hens. Two such birds, K134 and M408 were studied for comparison with the abnormal birds. These were entirely normal females as to all external structural characters. K134 was a Barred Plymouth Rock and Black Hamburg cross. She laid 184 eggs in 1913-14, and 84 from October to June of 1914-15, at which time she was killed. M408 was a Rhode Island Red and had laid 96 eggs up to the time of her death which occurred before she was a year old. No. 1422 was a White Leghorn sent to the Station by Professor Atwood of West Virginia, because he thought she might be a hermaphrodite. Her behavior, however, at Maine was that of a perfectly normal female. Her egg record shows 25 eggs during the two months of September and October while she was at Maine. During the winter she laid no more and died in February. There were no male second sex characters present in any of these birds. We shall see later in detail that this habit of 
treading hens has no evident basis in the structure of the reproductive apparatus.

The external characters of four of the Holland birds is shown in their photographs (figs. 1 to 4). Unfortunately 1425 died before she was photographed. None of these birds look like entirely normal females or males. No. 1429 (fig. 1) appears the most female and 1426 (fig. 4) the most male. They all have large combs, 1426 the largest, and 1428 the smallest. The wattles on 1426 and 1428 are larger than on the other two. The spurs are large on 1427 and 1429, and very small on 1426 and 1428 . Quite evidently these three so-called secondary sex characters do not correspond with body shape and carriage, as the most male has small spurs and the most female large comb and spurs. None of these five birds ever laid an egg or showed any sex behavior. They stood around the pens in a perfectly indifferent manner and never offered to fight either pullets or cockerels.

Atwood's hermaphrodite was also unfortunately not photographed. The records show that she had a small comb, large spurs, male carriage, female body shape, and that she was hennyfeathered. She had been presented to the Station by Mr. Atwood of West Virginia because of her hermaphrodite characteristics. Her behavior was watched while she was here at the poultry plant, and that proved to be also hermaphrodite in that the bird fought both males and females. Normally in the fowl females fight only with females and males only with males. She is recorded as "a great fighter." In fact, she met her death as a result of a fight after she had been transferred from one pen to another. The detailed account of structure in a later section of this paper shows that this bird had a hermaphrodite gonad, but that the germ cells were immature.

Bird 1349 was raised on the Station poultry plant, a cross between a Barred Plymouth Rock and a Game. It was clearly a female when it first reached maturity, but gradually developed more and more male characters, until at the time of its death, it was rather strongly male of the game type. Figure 5 was photographed during the moult, but shows the male carriage. The size of comb and spurs was typically male at the time of 
death. There were no wattles, the head being typically female in this regard. There were no true sickle feathers in the tail, although the tail was better developed, i.e., more towards the male type than in the normal female. There were no typical male hackle or saddle feathers. This bird was completely a hermaphrodite as to behavior, as it was observed to act alternately as a male and as a female in copulation. It never laid an egg. The bird was generally kept in a coop by itself except when being watched under special conditions to record its behavior. When put in a pen with pullets, it would act as a male, but as a female when put in with the cockerels. Finally one day when it was put down in a yard with some other hens to observe its behavior, it started to fight and was dead in five minutes. Reference in the later sections of this paper will show that the structure of the gonad at the time of death indicated that it was changing over from ovary to testis.

Bird 1616 (fig. 6) was sent to the Station as an abnormal cockerel by Dr. Dexter from Michigan in May, 1915. The bird was a cross between a Rhode Island Red male and a Plymouth Rock female. He was a year old when sent to Maine. For the Michigan period of his life, he is described as entirely hen-feathered and except for the head which is that of a rooster, he looked like a hen. He was very active and crowed a great deal more than usual. The other roosters chased him all over the farm, and the hens would not permit him to copulate with them, although he made frequent attempts to do so. After he reached Maine the female characters became more pronounced and the bird was recorded as a crowing hen. On July 31 she laid an egg, and between that time and August 25 she laid 12 eggs in all and nested twice. From then on she laid no more eggs and began to become more malelike in appearance. She was killed on March 15, 1916, and at that time her external characters were a mixture of male and female. She had no spurs, merely slight knobs such as all females have. She was very fat. She had no saddle feathers, but the hackle feathers were partly male. These hermaphrodite external characters correspond to the anatomical conditions deseribed later - that is, the bird has an ovotestis, with 
indications of recent or present activity in both the male and female parts of the gonad.

The study of the external characters and behavior of these hermaphrodite birds shows a great variety of combinations. Evidently the body shape and carriage and the plumage hang together more consistently as secondary sex characters than the spurs, comb and wattles. The latter group vary too much to be considered as proofs of maleness or femaleness. Sex behavior varies all the way from complete indifference to active reproduction. Three of the birds show double sex behavior acting as a male or female under different conditions at the same general period, or showing a gradual change from the behavior of one sex to that of the other. A case somewhat similar to that of 1616 has been described by O. N. Eastman in the Poultry Advocate for September, 1916. At first he did not know whether to class this bird as a pullet or a cockerel, but as she became more mature she looked like a pullet with a head like a cockerel. She began to lay in November, 1915, while housed in a pen with pullets and one cockerel. This one cockerel chased her so incessantly, as one male bird does another, that she had to be removed to a pen with only pullets. In August, 1916, she was seen to chase and mate with a pullet, and she repeated this behavior several times. This comparison will be taken up again after the full description of the anatomy and histology of the sex organs of these birds.

The two guinea chicken hybrids were entirely male in external characters, but absolutely indifferent as to behavior. They stood around the pens in much the same way as the Holland birds, taking no interest in either males or females. We shall see later this indifferent behavior is not accompanied by any gross abnormalities in the form of the reproductive organs - that is, not to such anomalies as an oviduct or oocytes, but to a lack of differentiation in the testis tissue. 


\section{WOLFFIAN DUCTS IN NORMAL FEMALE BIRDS}

Before describing the internal structures of this series of abnormal birds, it is necessary to mention certain points of normal bird anatomy which have been observed in this connection. Many of these points have already been described by Goodale. Our own observations are recorded here simply in corroboration of his, and because in certain particulars our evidence is more detailed. The normal reproductive system of a male bird comprises two testes and two vasa deferentia. The normal reproductive system of a female bird includes a left ovary and a left oviduct. The right ovary and oviduct start to develop in the embryo, but stop before long so that they do not function in the adult. By the fifth or six day, according to Semon, the right ovary is already smaller than the left. The right oviduct forms as a right Mullerian duct, and usually degenerates along with the ovary. However, this duct may sometimes continue to grow and persist in the adult as a non-functioning oviduct. There are fairly frequent cases of this recorded among the autopsies of the birds of the Maine Experiment Station poultry plant.

Every embryo female chick has besides its two gonads and two Mullerian ducts, two Wolffian ducts which have been supposed to degenerate in the female as the Mullerian ducts do in the male. The statement in Lillie's "Development of the Chick" reads as follows: "In embryos that become females, the gonad develops into an ovary, the Wolffian duct disappears or becomes rudimentary, the Mullerian duct develops into the oviduct on the left side and disappears on the right side."

In studying the anatomy of the hermaphrodite birds, the kind of ducts present was at first taken as an indication of sex-that is, the presence of vasa deferentia was regarded as a sign of maleness, and the presence of an oviduct as the corresponding sign of femaleness. According to this criterion, all these birds were hermaphroditic as they had a left oviduct and two vasa. The vasa were small ducts which had to be searched for in the peritoneum but sections showed them to be tubes lined with columnar 
epithelium, surrounding a distinct lumen, and therefore impossible to be confused with either bloodvessels or nerves.

The same condition of ducts was found in bird No. 1422, the bird sent from West Virginia with a record of treading hens. Everything else about the anatomy of this bird was that of a normal female-she laid eggs and showed no abnormal behavior after reaching Maine. The suspicion arose that these small non-functional vasa deferentia of the hermaphrodites might signify simply an embryonic condition,- that is, persisting Wolffian ducts - rather than maleness. Further, the fact of finding them present in 1422 , otherwise a normal female, suggested the possibility of their being a normal feature of the anatomy of an adult female bird. In Lillie's "Development of the Chick" there occurs the following statement: "In the female, the Wolffian duct degenerates; at what time is not stated in the literature, but presumably along with the Wolffian body." The persistence of the ducts of the other sex in adult vertebrates is not an unheard of phenomenon,-in fact, it is the normal condition in the common leopard frog for the Mullerian ducts to persist in the adult male.

To work out this point, as to how long the Wolffian ducts persist in the female bird, dissections were made of a number of just hatched chicks and chicks from pipped eggs, seven of which proved to be females, and of five laying hens. All of them had Wolffian ducts. They were not as large as in the male-in fact, sometimes they looked like white threads along the peritoneum lateral to the ureter at the posterior end, crossing it about half way between cloaca and gonad, and extending further anterior than the ureter near the midline to the remnants of the mesonephros. Sometimes they were as large as normal, but never had as many coils at the posterior end. Figure 7 is a dissection of one of the laying hens. To be sure that this white line was not a nerve or bloodvessel, parts of it were sectioned in each bird. The columnar epithelial lining identified it unmistakably (figs. 8 and 9). Figure 8 shows the vas alongside of an artery, a vein, and the ureter. Each is easily identified. These ducts show variation in structure. Sometimes 
they are single straight tubes, sometimes they show the characteristic coils of a vas. Always toward the anterior end, and sometimes posteriorly also they have branches. These are probably remnants of the connection with the mesonephrie tubules in the embryo.

In the laying hens, it is sometimes hard to identify the Wolffian duct on the left side on account of the coils of the large oviduct. That it persists on the left as well as on the right side, however, is established beyond a doubt by the fact that it was found on some of the laying hens, and also by the fact that all seven of the young female chicks had two Wolffian ducts. We agree then with Goodale that the presence of Wolffian ducts in an adult bird is not necessarily a sign of maleness.

\section{ANATOMY AND HISTOLOGY OF ABNORMAL BIRDS}

The internal structure of this series of abnormal birds shows varying degrees of abnormality, and the interest of the study lies chiefly in seeing whether there is a close correspondence between these and the abnormalities of external structure and behavior. We have seen that the normal female has two Wolffian ducts of varying sizes, besides the left ovary and oviduct, so that the presence of Wolffian ducts is not a sign of maleness. No oviduct has, however, been found in any male, so its pressence may be considered a sign of femaleness of internal structure. The external appearance of the reproductive organs has proved to be insufficient to distinguish between an ovary and a testis. An organ with a few projecting oocytes may be partly testis, and an organ without any visible oocytes may be ovary, testis or both. In deciding whether certain tissue is ovary or testis, the only indisputable criterion is when it has oocytes or spermatozoa. The general structure of the organ is, however, usually sufficient to show the difference in sex even when in an inactive condition, the testis being composed of tubules with a small quantity of connective tissue between them, and the ovary being largely stroma. However, there are some intermediate conditions found when it is difficult to sex the organ as they both develop from a stage when the sex cords grow 
out from the mesonephros into the germinal epithelium. The interstitial cells might be used as an index of sex, because of their consistent absence in Barred Plymouth Rock males over six months of age, if it were not for the fact that the gonads in some of these hermaphrodites seem to be cases of arrested development, and interstitial cells have been found in young just hatched males. The nests or groups of clear cells which normally fill up the discharged follicles and form the 'corpus luteum' are never found in the normal male. So their presence may be counted for femaleness.

Many cases of hermaphrodite birds have been described by various authors, with varying degrees of maleness and femaleness combined. More of them seem to be females which have developed some male characters than vice versa. Some of these abnormal combinations of external characters are associated with corresponding internal abnormalities and some are not. We shall discuss these cases after we have described the anatomical and histological conditions found in the hermaphrodites with which the present study is concerned.

In the description of their anatomy and histology the birds will be taken up in the order stated above - that is, beginning at the more female end of the series. Three of the birds with normal external characters and abnormal behavior were killed and dissected. No. 1432 was an entirely normal female with ovary and oviduct on the left, and persistent Wolffian ducts. Kl34 and M408 were killed and dissected and portions of the ovary preserved and sectioned. Both of these also proved to be normal females in structure. The ovaries were large with many protruding oocytes of varying ages. . The sections showed also many small oocytes embedded in the surface layer of the ovary. Both lutear cells and interstitial cells were present, in the same general arrangement and number as in the normal laying hen. It would seem then that the abnormal maleness of behavior in these three birds does not depend on any abnormalities of structure, there being no male organs present, or any male cells in the ovary, and there is present the full quota of female organs and cells. 
We shall consider next the Holland birds, and begin with the most female of them. No. 1429 is shown in dissection in figure 10. This is a photograph of a part of the back of the bird with all viscera removed except the urogenital system. The posterior end can be distinguished by the small piece of rectum remaining where the digestive tract was cut off slightly above the cloaca. The ducts can be seen, all connecting with the cloaca, and extending anteriorly to the region of the reproductive organ which lies at the most anterior end of the dissection. This one reproductive organ lies to the left and is an ovary with many oocytes visible to the naked eye, and a few very small orange spots like remnants of corpora lutea. The large round dark object to the left of the ovary is a tumor more than twice the size of the ovary. There is a normal oviduct with coils but the bird never laid an egg while in the Station flock. The two median ducts are the ureters. The right Wolffian duct shows its entire length plainly from cloaca to a spot opposite the ovary. It is somewhat coiled at the posterior end. At the anterior end, there is a slight enlargement, which proves in section to be a mass of tubules, resembling an epididymis. This is probably the remains of the mesonephric tubules, sometimes spoken of as a parovarium. A small portion of the left Wolffian duct shows in the photograph median to the oviduct. This is also somewhat coiled. There seems to be nothing male about the anatomy of this bird. It has an ovary and oviduct on the left and two Wolffian ducts. The only abnormal feature is the large tumor, which, of course, shows a diseased condition. The anatomy of the bird is, in short, that of a female in the non-laying condition with a large tumor. The histological study of the ovary shows it to differ in some points from both the old Campine past the laying condition and the actively laying birds, described in studies $I X$ and $X$. In general it resembles the Campine more closely; that is, there is a large relative amount of stroma and there are no very small developing oocytes (fig. 18). The oocytes present are of medium size and lie in normal follicles. In addition there are a number of cystic follicles filled with a watery fluid. These are visible to 
the naked eye, and some show in section in figure 18. There is the usual large number of nests of lutear cells in the theca interna, as shown in figure A. Some of these lutear cells present a feature not seen in any other bird, they contain a large number of acidophile granules. That these cells with granules are not the interstitial cells can be seen by comparing figures $A$ and B. Figure B is a group of interstitial cells from the stroma of this same ovary. The interstitial cells are smaller and more closely packed with granules. The only difference among the cells in figure $A$ is that some are clear and some have granules. They are the same as to size and nucleus. The number of real interstitial cells is small (fig. C). In various parts of the gonad, there are older lutear cells with the yellow pigment. Whether these corpora lutea represent discharged or atretic follicles it is impossible to decide, as the involution process has proceeded beyond the stage where this distinction can be made. The microscopical structure together with the gross anatomy show 1439 to be a female.

There is not much choice as to the order in which the next three birds shall be described, as the ducts of all three are of the female type, and the reproductive organs of all are indifferent enough to make it somewhat difficult to sex them.

The dissection of 1428 is shown in figure 11. The two Wolffian ducts are easily seen in this photograph, being of considerable size. The bird has a larger coiled oviduct than 1429 , and a lobulated reproductive organ on the left. This organ has a large watery tumor to the left of it, showing that it is also in an abnormal physiological condition. It is exceedingly difficult to sex this organ. It is largely composed of tubules, which radiate toward the periphery from a central connective tissue core. But the entire surface looks like an ovarian stroma (fig. 19) and all this connective tissue at the periphery and continuing down between the tubules contains many masses of the lutear cells normally found in the theca interna (figs. $19 t$ and $20 \mathrm{t}$ ). The tubules are in some places lined with characteristic columnar epithelium cells (fig. 20), but in most the cells appear to be breaking down (fig. 19). In the central core of 
this organ, there are some interstitial cells loaded with secretion granules (fig. D) also many streaks of tumor-like material. This bird is probably a female arrested in the development of its gonad earlier than 1429 . To be sure

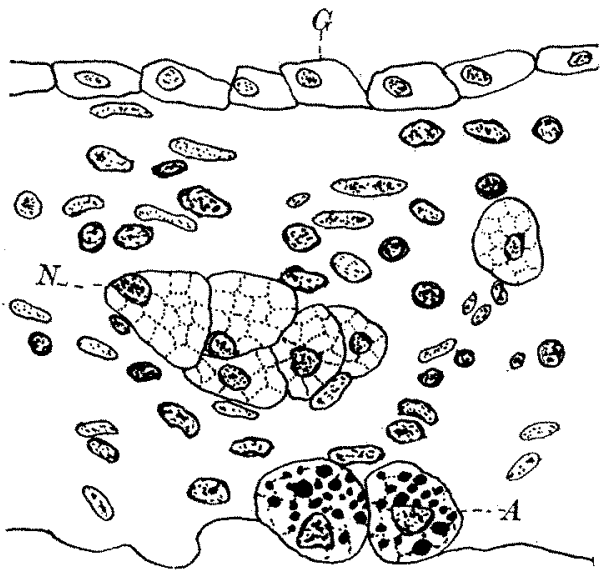

A

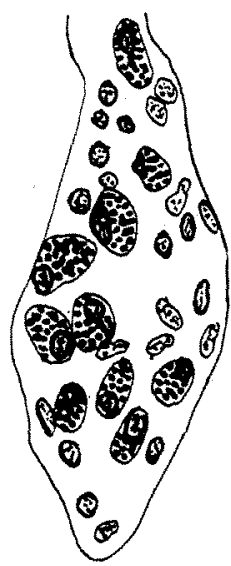

B

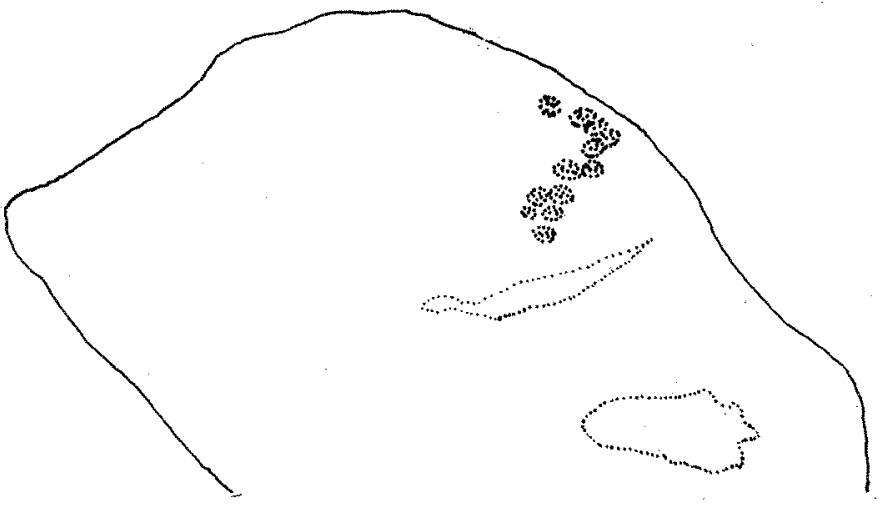

C

Fig. A Portion of follicle wall from ovary of $1429(\times 570) . \quad G$, epithelial layer; $N$, nest of lutear cells in theea interna; $A$, lutear cells containing acidophile granules.

Fig. B Portion of stroma of ovary from 1429 showing a few interstitial cells loaded with granules $(\times 570)$.

Fig. C Portion of periphery of ovary from 1429 , showing the small number of interstitial cells present $(\times 264)$. 
the tubules look like testicular structures, but they may instead be mesonephric, a condition which might be found in an embryonic ovary. In fact, it looks much like the ovary of the just-hatched chick shown in figure 32. The presence of the lutear cells in groups in the stroma also suggest arrested development, as in the normal development of the egg follicle, there is a stage before the theca layers are added when only the granulosa is present, but the nests of lutear cells are conspicuous in the stroma near the young follicles. Although the lutear cells are present they have not gone through their full development,

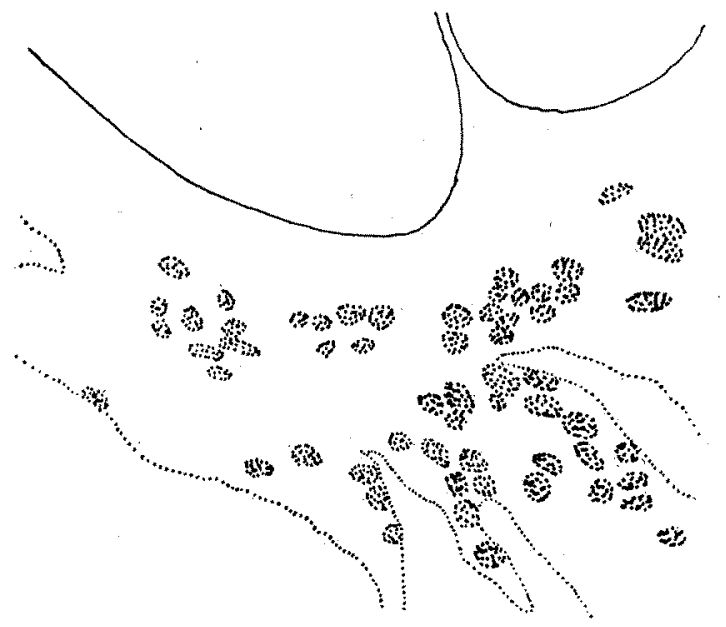

Fig. D Portion of connective tissue core of gonad from 1428, showing numerous interstitial cells $(\times 264)$.

as there is no trace of the yellow pigment in any part of the gonad. The dissection of 1427 is shown in figure 12. The two Wolffian ducts are shown in the photograph, the right one with a distinctly enlarged anterior end, which is of the nature of a mass of mesonephric tubules or parovarium, as shown by section. This bird has also a coiled oviduct and a lobulated reproductive organ on the left. Here again is a large dark. tumor posterior to the reproductive organ as in 1429. Figure 21 is a section of this organ. It seems largely composed of solid cords of cells. There are no oocytes and no hollow tubes, 
so it is difficult to be sure of the sex. A comparison with sections of just-hatched ovaries and testes seems to throw a little light on its nature. Even at this stage the testis has distinct tubules, but in the ovary, the oocytes are not yet enclosed in follicles, but the germinal epithelium has grown down into the stroma in solid cords (fig. 32). The appearance of the cortex is not unlike that of 1427 . Sections of 1427 stained with Mallory's connective tissue stain show no interstitial cells present, and also no lutear cells. The probable conclusion then as to the internal structure of 1427 is that it is a female with an inactive gonad even less differentiated than in 1428. Development was probably checked by some pathological condition, of which the large tumor may be an index.

The dissection of 1425 (fig. 13) is not very different from that of 1428 or 1427 just described, except for the absence of a visible tumor. Sections show the posterior portion of the gonad to be filled with streaks of a secretion which resembles the substance of the tumor in 1429. This would indicate that it is in a similar pathological condition, although no separate tumor has been formed. Externally the reproductive organs of these three birds could scarcely be distinguished. Internally, however, the gonad of 1425 is more like that of 1428 , in that the central portion is composed of tubules with distinct lumena, as shown in figure 22. There is no sign of any mitoses in any of the tubule cells, so they are probably of mesonephric origin,-that is, undifferentiated sex cords without any primitive germ cells. The peripheral portion has probably as in 1428 originated from the germinal epithelium. There are no interstitial cells present in the stroma, and the number of groups of lutear cells between the tubules is less than in 1428 . The presence of any of the latter elinches the diagnosis of this bird as a female arrested in development. The fewness of these cells may place it as more primitive than 1428,- - that is, in between 1428 and 1427. Unfortunately there is no record or photograph of external characters to compare with the other two.

The last of the Holland birds in the series, 1426, is distinctly different from the others in its structure. It has two repro- 
ductive organs, and the large coiled oviduct of a laying bird (fig. 14). At the posterior end, to the right of the cloaca is a crumpled mass, which is apparently a partly developed right oviduct. No Wolffian duct was found on the left side, but the immense size of the oviduct made it difficult to dissect on that side. The organs of the two sides are very different in external appearance, as can easily be seen in the photograph. The right one is an active testis and the left one an inactive ovary. Figure 23 is a photograph of a section of the testis, a large mass of tubules with very little connective tissue between them. Part of this same section is shown at greater magnification in figure 24. This resembles a section of a normal active testis. The black threads are fully formed spermatozoa, and they are bunched into groups for each Sertoli cell in normal manner. The vas, strange to say, is no larger than in the birds with no organ on this side, and not as much coiled as the one in 1429 . The left reproductive organ closely resembles the ones in 1428,1425 and 1427 in external appearance. On the surface are a couple of depressions which might be degenerate oocytes or discharged follicles. One place shows an orange masss like a corpus luteum. Histologically the main substance is like that of 1427 , and resembles the stroma of an ovary with solid cords of cells in it, but no oocytes (fig. 25). The peripheral tissue, however, looks like a thickened germinal epithelium and contains several large spaces which may have been oocytes. In the place with the orange spot on the surface there is a mass of tissue containing groups of cells with yellow pigment material, as described for discharged or atretic follicles in study $\mathrm{X}$. The entire stroma shows great streaklike masses of secretion taking acid stains, as in the organs of 1425 and 1428. In one limited area of the ovary, there are a few interstitial cells filled with granules. In both ovary and testis there are a few nests of lutear cells near the surface. This condition in the testis is shown in figure $\mathrm{E}$, as it is unusual to find them in a testis, and probably indicates the generally unbalanced sex condition of the animal which looks as though it might be changing from female to male. This is the most interesting of the Holland birds, absolutely indifferent as to 
sex behavior and yet with sperm in the testis, and at least one corpus luteum remnant on the ovary, and the oviduct of a laying hen. In external appearance, it is more like a male than the others, which fact correlates well with the active condition of the testis and inactive diseased ovary with only one corpus luteum scar. The interstitial cells can scarcely be held accountable for the male secondary sex characters, as the only ones in

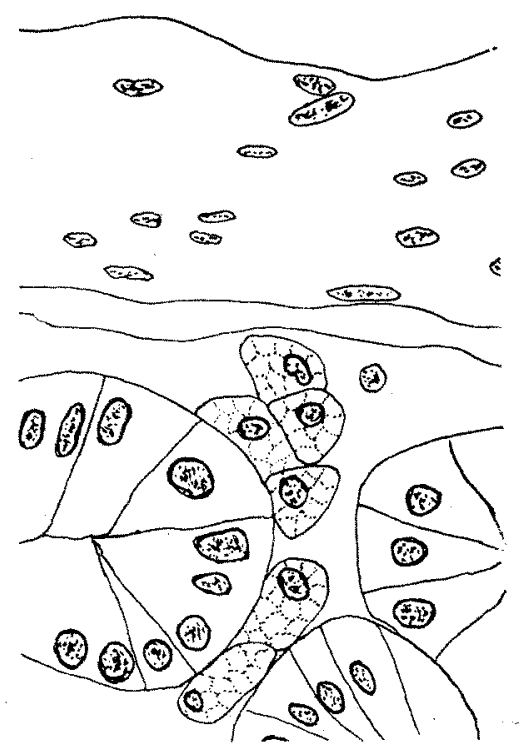

Fig. $\mathrm{E}$ Portion of testis from 1426, showing some lutear cells between the seminal tubules at the periphery $(\times 570)$.

an active secreting condition are a few in the ovary. This bird is the most balanced hermaphrodite of the series, and closely resembles bird 16, described by Pearl and Curtis, as to its internal structure, except for the active condition of the testis.

A comparison of these five Holland birds shows a general correspondence between the degree of femaleness of their external characters and their internal structure. They are all fundamentally females in which the ovary for some reason has failed to reach complete development. In all but 1429 and 1426 the lutear cells are immature. In 1426 , a testis has developed 
on the right side. They are all of them, however, entirely indifferent as to sex behavior, and such so-called secondary sex characters as comb, wattles, and spurs vary regardless of internal structure. The interstitial cells vary too much in their distribution to be considered the cause of the general maleness or femaleness of the external characters, and they cannot have anything to do with the large combs and spurs, as the distribution of the two does not correspond. For example, 1427 has no interstitial cells and a very well developed comb and spurs. No. 1428 with the most interstitial cells has the smallest spurs. No. 1429 in spite of having the most female carriage and most normal ovary has longer spurs than 1426 , which is the most male of the series. Spurs and combs are too variable to be considered distinctively male secondary sex characters. On the other hand, the distribution of the interstitial cells does not correspond with either the maleness or femaleness of body shape and carriage. However, the only one of these five birds with any lutear pigment worth mentioning is 1429 , the one at the more female end of the series. This may be significant. The cause back of the lack of development of oocytes and lutear secretion may be the general abnormal physiological conditions indicated by the tumors and pus present.

We shall consider next the anatomy and histology of the three birds with hermaphrodite behavior. Atwood's black hermaphrodite has two Wolffian ducts and an infantile oviduct (fig. 15). On the left is a large irregular organ. The left half of this lefthand reproductive organ is not unlike the organs found in 1427, 1425 and 1428,- - that is, it is irregularly lobed, but the one largest posterior lobe looks more like a testis in the smoothness of its surface than any of the other organs referred to. The right half of the left hand organ appears like an ovary with small oocytes all over the surface and two small orange spots like corpus luteum remains. Sections show this organ to be an ovotestis. The part which appears externally like a testis is composed of tubules. In none of them are any advanced stages of spermatogenesis; the majority of the cells 
are spermatogonial cells or spermatocytes in synizesis. The portion that resembles an ovary in external appearance has distinct ovarian tissue on the periphery, but the center is filled with tubules in an even less developed condition than those of the part already described (fig. 26), but distinctly testicular as they are filled solid with cells, not hollow like mesonephric tubules. On the right side of the body there is an enlargement of the anterior end of the Wolffian duct and this, upon being sectioned, appears like the center of the ovarian portion, a mass of small tubules with inactive cells (fig. 27). The ovarian portion of this organ contains oocytes of many sizes. Some of them are contained in normal follicles with the characteristic nests of lutear cells in the theca interna, but the majority are beginning to degenerate. Many groups of these lutear cells lie in the connective tissue of the stroma between the follicles and a few among the testis tubules at the center of the ovary and among the tubules of the small testis on the right. In three places the sections passed through atretic follicles packed with these cells here containing clumps of the yellow lutear pigment. This histological structure represents the orange spots visible on the surface to the naked eye. No interstitial cells were found in any portion of the organ. This bird is a potential hermaphrodite in its internal structure, a fact of especial interest in view of its hermaphroditic behavior. The structure looks as though it were changing from female to male. The oocytes are mostly starting to degenerate and some atretic follicles are already filled with lutear cells containing the characteristic pigment. The presence of lutear cells among the testis tubules looks as though the tubules were growing from the center outward and forcing their way into the ovarian tissue at the surface. But neither the ovarian or testicular tissue was in active condition when the bird was killed.

No. 1349 is the second bird with hermaphrodite behavior. Figure 16 is a dissection of the reproductive organs. In this bird, they were dissected out of the body and preserved as photographed before the Wolffian duct situation had been worked out, so that it is possible that the bird possessed the normal 
two ducts. The organs shown in the photograph are a coiled oviduct and a gland which proves to be mostly a testis (fig. 28). Some of the tubules show spermatids and developing sperm (fig. 29). This organ was sectioned in eleven different regions and only three showed any structures other than testis tubules. One of these parts is shown in figure 30 . This strongly resembles the indifferent ovary of 1426 and 1427, so we are probably justified in calling this an ovotestis. One other portion which was not testicular is most remarkable in structure (fig. F). It is a large solid collection of smaller masses of lutear cells partly degenerated and containing a few yellow pigment granules (fig. G). There is enough of this pigment to give the mass a yellowish tinge to the naked eye. There are also nests of lutear cells in normal undegenerated condition between the tubules of the testicular portion, as shown in figure $H$. This organ looks as though it had been an ovary and was largely changed over toa testis. It was certainly mostly testis when the bird was killed. But the yellow pigment must represent either discharged or atretic egg. follicles and the groups of lutear cells between the tubules suggest that these tubules have somewhat recently invaded ovarian tissue. It is especially significant that these groups of lutear cells lie mostly toward the surface of the gonad.

These two birds with active sex behavior have reproductive organs in a less active condition than 1426, with absolutely indifferent behavior. In fact, 1426 has mature sperm in the testes, while 1349 has either immature or degenerate sperm, and Atwood's bird had cells no further developed than the synizesis stage. On the female side, the oviduct of 1426 is much larger and more coiled than that of either of the other two birds, but they all have signs of having had active ovaries,that is, they have several degenerating oocytes, many immature lutear cells, and several lutear pigment masses. No. 1426 has less of the ovarian tissue remnants, just as it has a more advanced testicular structure. There are a few interstitial cells in 1426 , but none in either of the active birds, so that active sex behavior can scarcely be based on these. Also the differences cannot be laid to the lutear cells, as they are present in all three. 

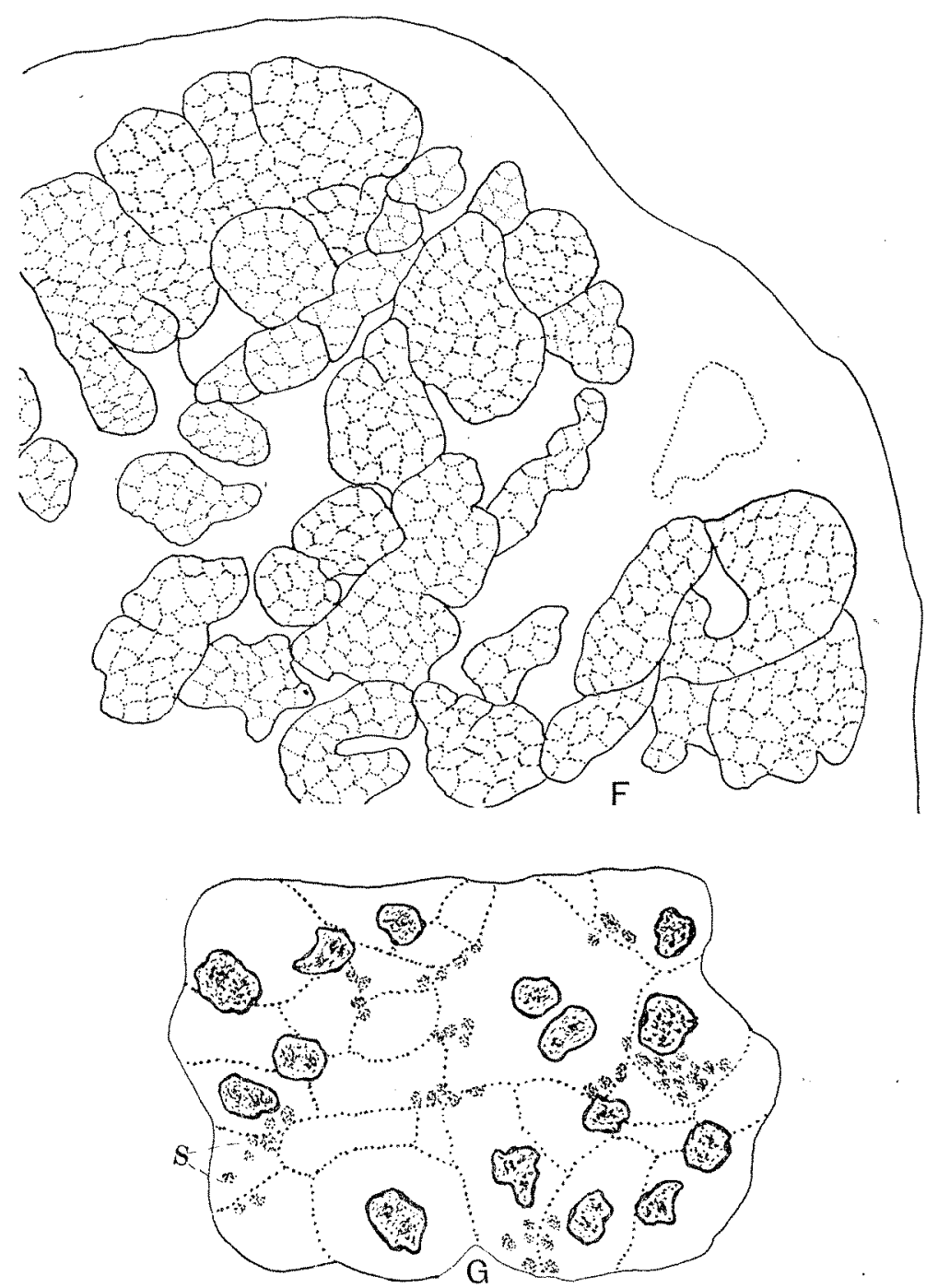

Fig. F Section of old ovarian tissue from gonad of 1349, showing stroma filled with groups of lutear cells resembling those in discharged or atretic follicles $(X 100)$.

Fig. G Group of lutear cells from figure $F$, showing masses of yellow secretions $(\times 950)$. 
The third of these genuine hermaphrodites is 1616, the bird sent by Dr. Dexter from Michigan. The anatomy of its reproductive organs is shown in figure 17. There is a large coiled oviduct and two Wolffian ducts. There is one large lobulated reproductive organ on the left. This is larger than in any of the other birds studied. The surface of this organ has oocytes of varying sizes scattered at various places, but the whole texture of the lobes is more solid than in a normal ovary. There are fourteen corpora lutea remnants. The egg record of this bird shows that she laid 12 eggs and nested twice, so that in this case, the orange spots just represent discharged instead

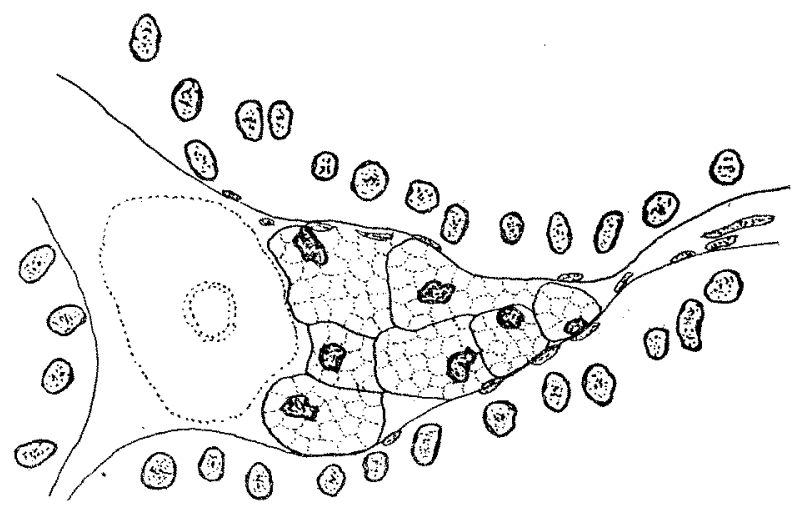

Fig. $\mathrm{H}$ Section of testicular tissue from gonad of 1349, showing a group of lutear cells in a space between seminal tubules $(X 570)$.

of atretic follicles. At the anterior end of the right Wolffian duct is the same sort of enlargement as has been mentioned for Atwood's bird. The microscopical study of the large organ shows it to be an active ovotestis with the testis portion in the more active condition when the bird was killed. The main body of the organ is testis tubules with sperm in the lumens. The small organ on the right is also active testis with sperm. But the peripheral portion of the large organ is distinctly ovarian. It consists of thickened stroma packed with interstitial cells like the old Campine (fig. I). It contains oocytes of all sizes, small ones with only a granulosa layer to the follicle and large ones with nests of lutear cells in the theca interna. There 
are not nearly as many oocytes as in a normal ovary. Finally it contains a few discharged follicles; one recently discharged with the cavity still large and the granulosa sloughing off into it, a second with the cavity just obliterated by the shrinking of the walls, and a number with the degenerating lutear cells in the center containing the yellow pigment, exactly as in normal birds. This is normal ovarian tissue, but there is not so much of it as there is of the testicular tissue. The composition of this organ is more like Atwood's bird than any other, in the proportion of male and female parts. The point in which this bird

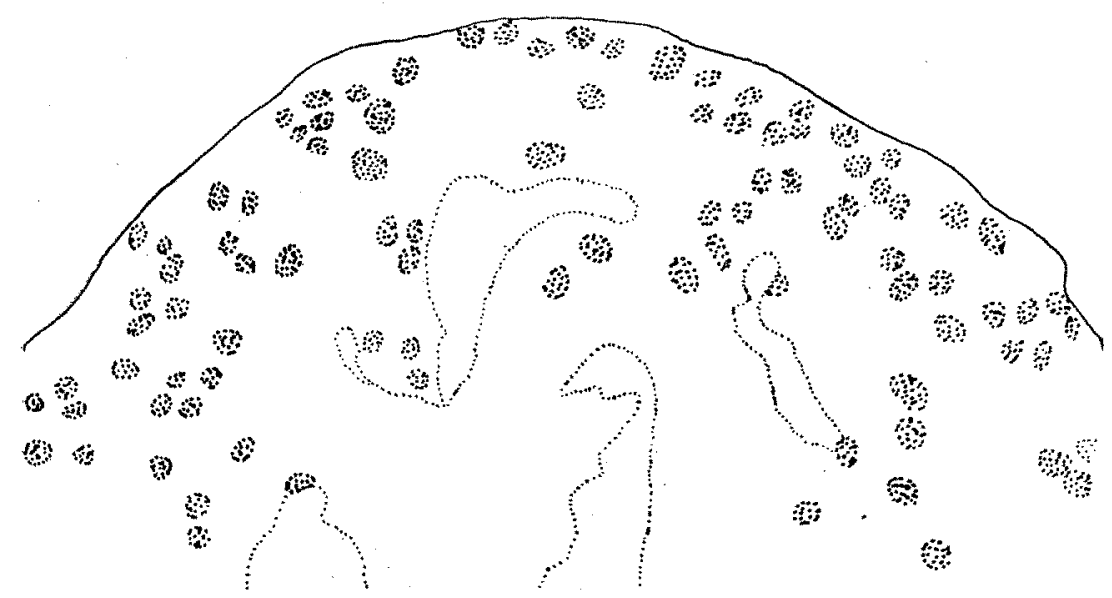

Fig. I Portion of periphery of gonad from 1616, showing numerous interstitial cells $(\times 264)$.

differs from all others studied is that both the ovary and the testis show signs of very recent or present activity.

It is.interesting to compare the structures found in these birds with those of some of the hermaphrodite birds previously described by other authors. In 1889, Brandt described eight hermaphrodites of varying structure, seven of which he considers modified females. In 1906, Shattock and Seligmann described a two year old Leghorn with an ovotestis. Also of interest are the hermaphrodites with ovary and testis described by Pearl and Curtis, the four mule pheasants, which are sterile females with some male secondary sex characters, described by 
Smith and Thomas, and a gynondromorph pheasant described by Bond in 1914. The oviduct is an almost constant feature in these birds. The only bird without an oviduct is one described in Brandt's paper. Shattock and Seligmann's Leghorn had two oviducts. Five of Brandt's birds had abnormal oviducts, either anterior or posterior end being closed. In the rest, the female ducts were normal, just as in the birds described in this paper. In most of these papers, nothing is said about the vasa deferentia. Brandt shows one picture of sections through two persistent Wolffian ducts, the one on the right side being larger than the one on the left. In the bird which he claims is a male with female characters developed, he says there are no vasa deferentia. Pearl and Curtis's bird 16 had an oviduct on the left for the ovary, and a vas on the right for the testis. Shattock and Seligmann's bird had two vasa.

In comparing the structure of the reproductive organs, there again seems to be a preponderance of female over male. Four of Brandt's birds had ovaries in more or less embryonic or degenerate condition. The four mule pheasants of Smith and Thomas had ovaries composed of stroma and interstitial cells, with no oocytes. Nos. 1427, 1425 and 1428 of our birds belong to this type. One of Brandt's birds and 1429 of this paper had normal ovaries with oocytes. An ovotestis or mixed gland was present in two of Brandt's birds, in Shattock's Leghorn, in Bond's pheasant, and in Atwood's Hermaphrodite, 1349, and the Michigan bird of the present study. No. 1426 and Pearl and Curtis's bird No. 16 both had an ovary on the left and a testis on the right, with the difference that while in both, the ovaries were inactive, the testis in 1426 was active and that in 16 was not. One bird described by Brandt had two testes, one on each side. Hammond Smith is also quoted by Bond as describing three birds with some female secondary sex characters with normal testes present. In most of these birds, previously described, the gonad of whichever sex showed no signs of activity of the germ cells The first of Brandt's birds is the one possible exception on the female side. Several of the birds in this study, however, show signs of past or present 
activity of the ovary. No. 1429, Atwood's bird, and the Michigan bird have many oocytes of varying sizes on the periphery. No. 1349 and 1426 have some cystic oocytes, while there are corpora lutea representing discharged or atretic follices on four birds, 1426, Atwood's bird, 1349, and the Michigan bird. No. 1429 has no discharged follicles, nor any very small oocytes. No signs of ovarian activity, either past or present could be discovered in the other three birds, 1428, 1427, 1425.

The only birds with active testis in which sperm were observed are Bond's pheasant, 1426, 1349, and 1616 described in this paper, possibly also the three birds of Hammond Smith, although we do not know how carefully the histology of these was studied. It should be noted that all eight birds described by the present authors may be interpreted as fundamentally females, some of them checked in the embryonic condition of the gonads, and some of them changing over to a male condition.

Next in the series of abnormal birds we have placed the guinea chicken hybrids. The anatomy of these is apparently that of perfectly normal males with two testes and two vasa deferentia. These were of normal size in one, and much enlarged in the other. That these testes, however, are not normal, is clearly shown in microscopic sections (fig. 31). There is no sign of tubules or any cells distinguishable as germ cells. The structure looks more like ovarian stroma than part of a testis, that is absolutely indifferent, whether ovarian or testicular in nature. In fact, it is probably neither, but simply an undifferentiated gonad, as in the early embryo. Neither are there any cells with the distinguishing marks of interstitial cells or lutear cells. This is, of course, an entirely different condition from that found in Guyer's guinea chicken hybrids, where there were many tubules and an abnormal synapsis either stopped the process of sperm formation or else resulted in abnormal spermatozoa. Poll has worked out the theory from his hybrid birds that the more closely related two crossed birds are, the more normal will be the spermatogenesis. This, however, does not explain how some male guinea chickens can have abnormal 
sperm formed and others have no trace even of seminal tubules in their structure.

\section{DISCUSSION}

The study of the anatomy and histology of this whole series of birds somewhat abnormal as to sex shows that they are all fundamentally female, except the guinea chickens. These are merely sterile males with consequent indifferent behavior. The hens with a tendency to tread other hens are normal active females. The eight other birds are fundamentally female, either undeveloped or degenerating. Every bird has in its embryonic development an undifferentiated sex stage as far as organs are concerned. It has the ducts for both sexes, and the gonad has the same early development regardless of whether it develops later into an ovary or testis. This undifferentiated gonad consists of a mass of sex cords growing out from the mesonephros covered over by a thickened germinal epithelium. If the bird becomes a female, the left Müllerian duct enlarges and the germinal epithelum proliferates and forms most of the reproductive organ. If the bird becomes a male, the Müllerian ducts degenerate, the Wolffian ducts become larger and coiled, and the sex cords become the main part of the reproductive organ. One of the Holland birds, 1429, is nearly a normal female. Three of the Holland birds, 1428, 1425, 1427, are evidently undeveloped females. They have infantile oviducts and embryonic ovaries. The other four birds are also fundamentally female, but show that the reproductive apparatus, has passed through a female stage and has become partly or largely male. In 1426, the ovary is partly embryonic, and partly degenerating, and a testis with active sperm has formed on the right side of the body. It has the oviduct of a laying hen. The other three birds have large gonads on the left side only and in all three cases the ovarian portion shows signs of degeneration and the testis portion signs of development. A transformation such as this can be easily understood from the embryonic development. The sex cords in the core of the gonad hypertrophy and form seminal tubules, while the oocytes and 
follicles in the germinal epithelium are crowded to the edge of the organ and degenerate. The primary cause back of this shifting of development we make no attempt to explain at present.

As to the relation of the secondary sex characters to the primary sex organs, there is shown by this study only a very general correspondence such as in body shape and carriage. Spurs, comb and wattles vary regardless of primary sex organs. The general correspondence might be accounted for in accordance with the theory that the ovary forms an external secretion that inhibits maleness. In the cases where the ovary is embryonic it has not matured sufficiently to form such a substance. In the cases where it has degenerated its influence is past. That would account for the fact that birds with both embryonic and degenerating ovaries exhibit some male characters.

The interstitial cells are elearly shown to have nothing to do with any of the secondary sex characters. Their distribution is not correlated with any such characters. The lutear cells, however, are found to be in distinct and definite correlation with the degree of external somatic femaleness. Even in these abnormal ovaries, they seem to keep to their normal process of development, fill up the atretic and discharged follicles and finally form the characteristic yellow pigment. Just as Pearl and Surface showed to be the case in the cow, so here in fowls the degree to which an individual remains somatically female, is precisely reflected in the amount of lutear tissue in the ovary, and vice versa.

The behavior of these birds presents some distinct anomalies. It does not entirely correspond to the external characters nor to the stage of development of the gonads. The behavior of the birds with embryonic gonads is indifferent, although the birds show some adult external sex characters. No. 1426 has mature sperm, but entirely indifferent sex behavior. However, 1349 and 1616 show the same changing sex behavior as they do external characters and internal structure.

A fuller discussion of the facts of normal and abnormal sex structures and behavior, with their bearing on theories of sex and secondary sex characters will be presented in a later paper. 


\section{SUMMARY}

1. The eight hermaphrodite birds studied are females with embryonic or degenerating ovaries.

2. Three of these birds were changing from a female to a male condition in respect to internal structure (gonads), external characters and sex behavior.

3. There is no structural counterpart for the abnormal behavior of one hen treading another hen.

4. The two guinea chicken hybrids studied had testes composed of undifferentiated tissue. This is a different condition from that found by Guyer in a guinea chicken hybrid, and therefore calls in question Poll's theory that the stage of germ cell development in hybrids depends on the closeness of the relation of the individuals crossed.

5. Development of comb, spurs, and wattles does not stand in direct quantitative relation to the sex of the gonad.

6. Body shape and carriage, have a general relation to the sex of the gonad.

7. The interstitial cells clearly have no causal relation to the secondary sex characters in the abnormal birds here described.

8. Amount of lutear cells or pigment is in precise correlation with the degree of external somatic femaleness exhibited by the individual.

\section{LITERATURE CITED}

Bond, C. S. 1914 On a case of unilateral development of secondary male characters in a pheasant, with remarks on the influence of hormones in production of secondary sex eharacters. Jour. Gen., vol, 3, p. 205.

BrandT 1889 Anatomisches und Allgemeines über die sog. Hahnenfedrigkeit u. über anderweitige" Geschlechtsanomalien bei Vögeln. Zeitschr. f. wiss. Zool., Bd. 48 , p. 101.

Eastman, Ourver N. Letter in American Poultry Advocate, vol. $\because$ p. 733.

Goodale, H. D. 1916 Gonadectomy in relation to the recondary sex characters of some domestic birds. Carnegie Inst., Washington, Publ. 243.

Gudernatsch, J. F. 1911 Hermaphroditismu: verus in man. Am. Jour. Anat., vol. 11, p. 267.

GUYER, M. F. 1912 Modifications in the testes of hybrids from the guinea and the common fowl Jour. Morph., vol. 23 , p. 45.

LrLire, F. R. 1908 Development of the chick. Holt \& Co., N. Y.

PeArt and Curtis 1909 A case of incomplete hermaphroditism. Biol. Bull., vol. 17, p. 271. 
PoLl, H. 1909 Zur Lehre von den sekundären sexual Charakteren. Sitzber. der Ges. Nat. Freund 6, Jahrgang '09, p. 331.

Seligmann and Shatrock 1914 Relation between seasonal assumption of eclipse plumage in the mallard and function of testicle. Proc. Zool. Soc., London.

Shattock and Selramann 1906 An example of true hermaphroditism in domestic fowl, with remarks on the phenomenon of allopterotism. Trans. Path. Soc. London, vol. 57, Pt. I, p. 69.

Smith, G. and Mrs. HaIg Thomas 1913 On sterile and hybrid pheasants. Jour. Gen., vol. 3, p. 39.

Smith, Hammond 1911 The Field, p. 34.

PLATE 1

EXPLANATION OF FIGURES

1 Holland bird 1429 .

2 Holland bird 1428.

3 Holland bird 1427.

4 Holland bird 1426.

5 Hermaphrodite 1349.

6 Michigan hermaphrodite 1616. 
SEX STUDIES. XI

PLATE 1

ALICE M. BORING AND RAYMOND PEARL

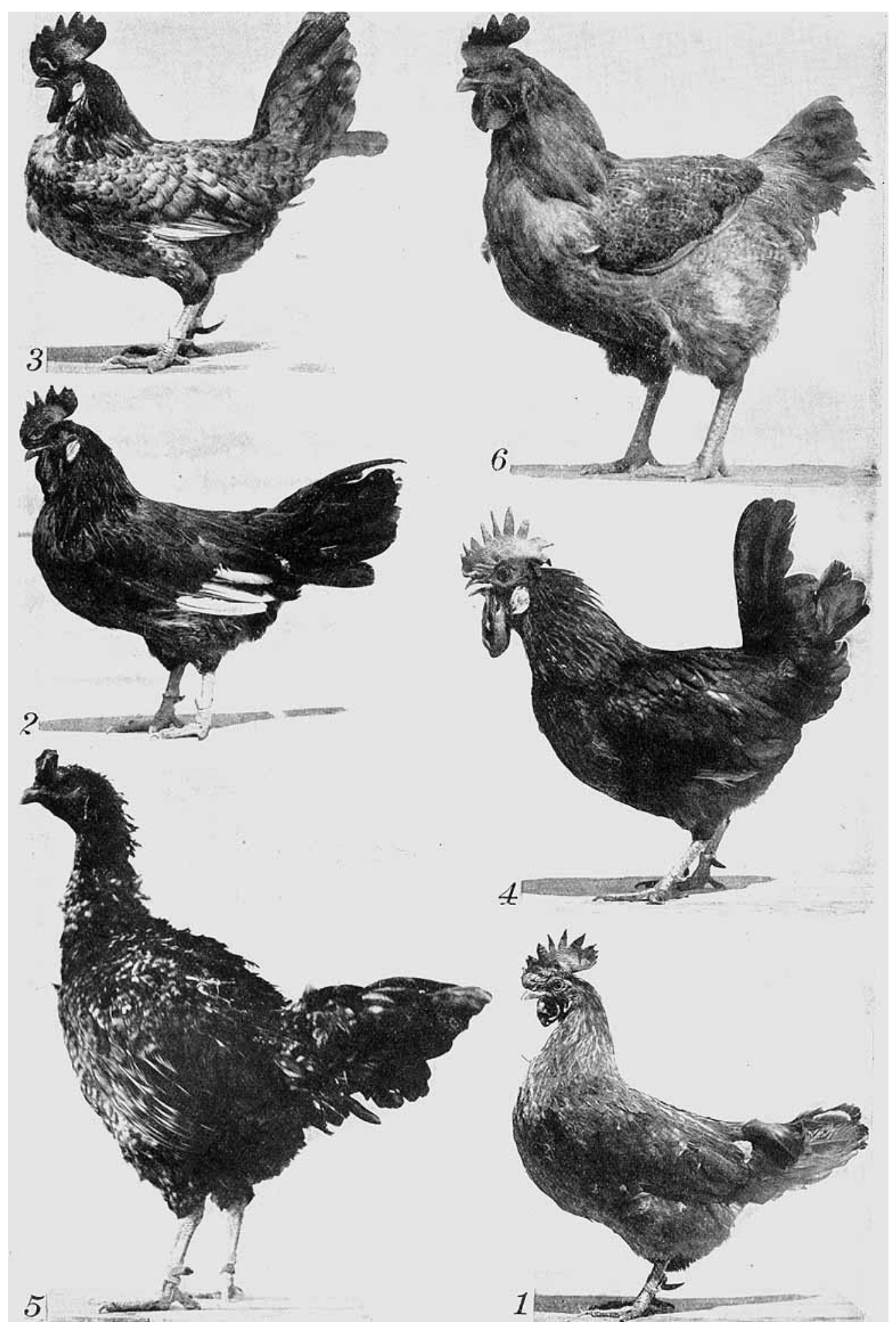


PLATE 2

EXPLANATION OF FIGURES

7 Dissection of urogenital system in a normal hen. $d$, oviduct; $o$, the ovary; $u$, a ureter; $v$, a vas deferens.

8 Section of ducts entering cloaca in a normal hen. $a$, is artery, $u$, the ureter, $v$, the vas deferens, or Wolffian duct.

9 Same as $v$ in figure 8 , showing columnar epithelium of the vas in a normal hen. 


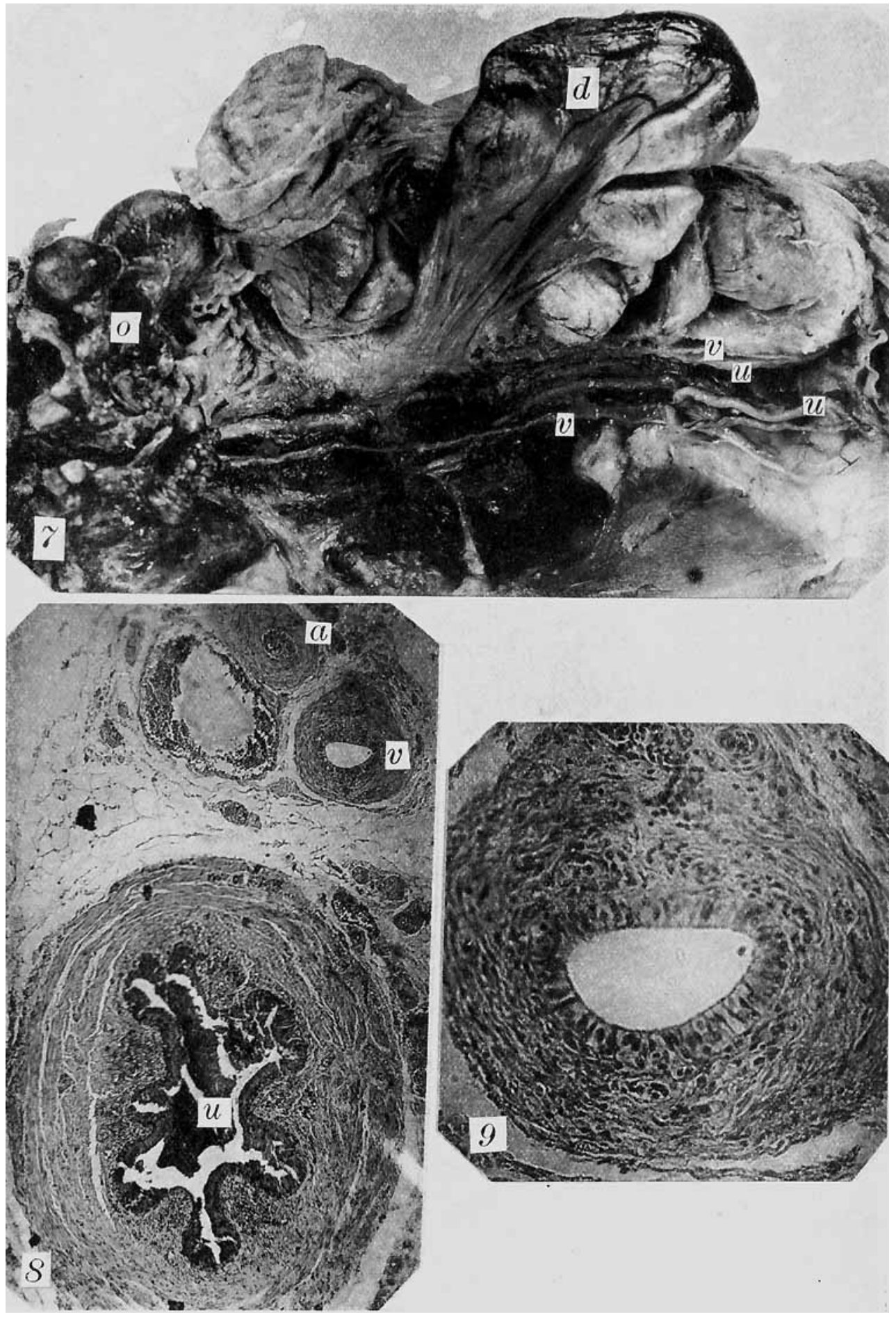




\section{PLATE 3}

EXPLANATION OF FIGURES

10 Dissection of urogenital system of bird No. 1429. d, the oviduct; o, the ovary; $r$, the rectum; $t$, the large tumor.

11 Dissection of urogenital system of bird No. 1428 d, oviduct; $g$, the gonad; $t$, the tumor.

12 Dissection of urogenital system of bird No. 1427. $d$, the oviduct, $g$, the gonad; $t$, the tumor. 
SEX STUDIES. XI

PLATE 3

ALICE M. BORING AND RAYMOND PEARI,

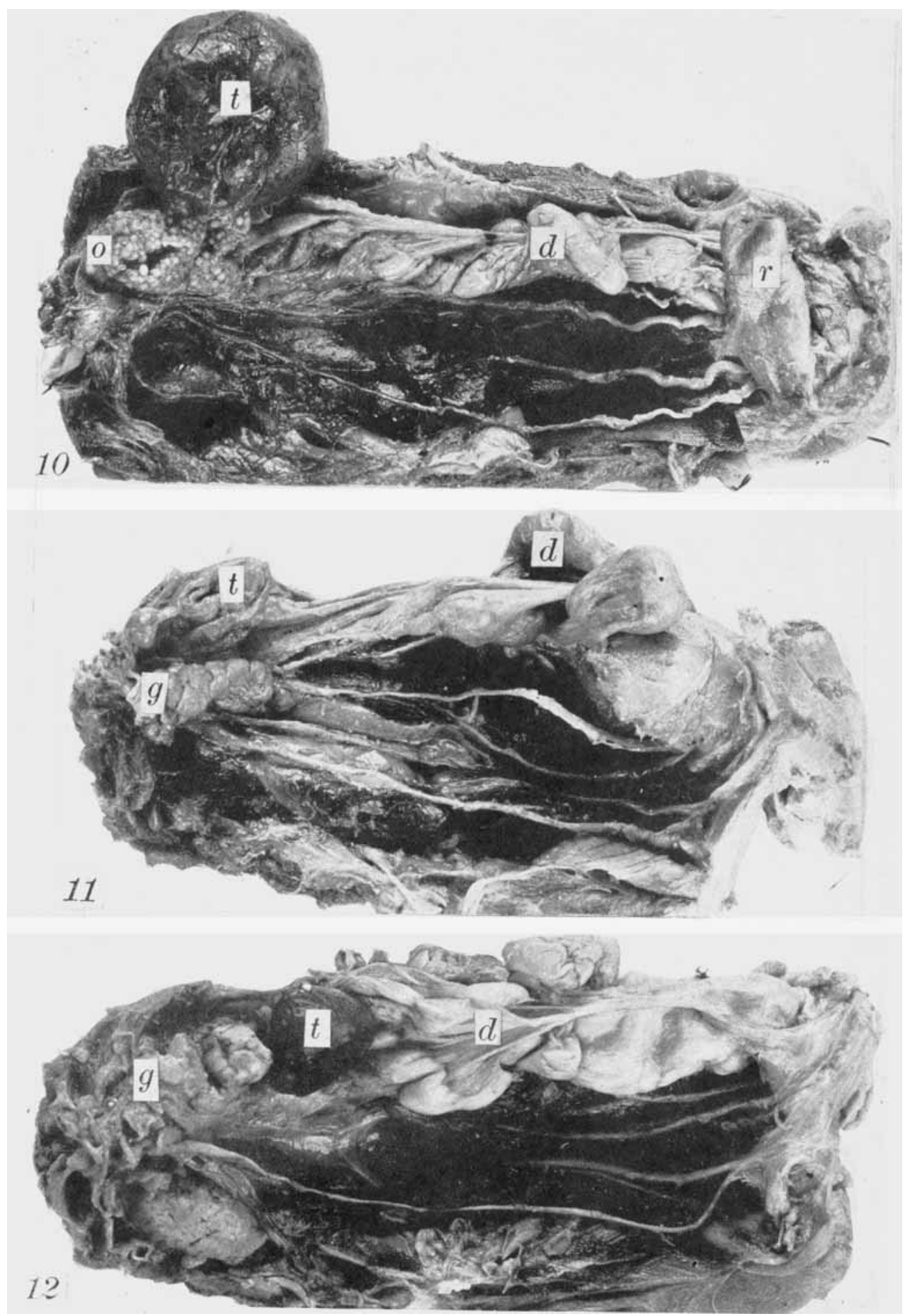




\section{PLATE 4}

\section{EXPLANATION OF FIGURES}

13 Dissection of urogenital system of bird No. 1425. $d$, the oviduct; $g$, the gonad.

14 Dissection of urogenital system of bird No. 1426. $d$, the large coiled left oviduct; $o$, the ovary on the left; $r d$, the crumpled right oviduct; $t s$; the testis lying on the right. 
SEX STUDIES. XI

PIATT 4

MTCE M. BOAINo 48D RAYMOND PEARL
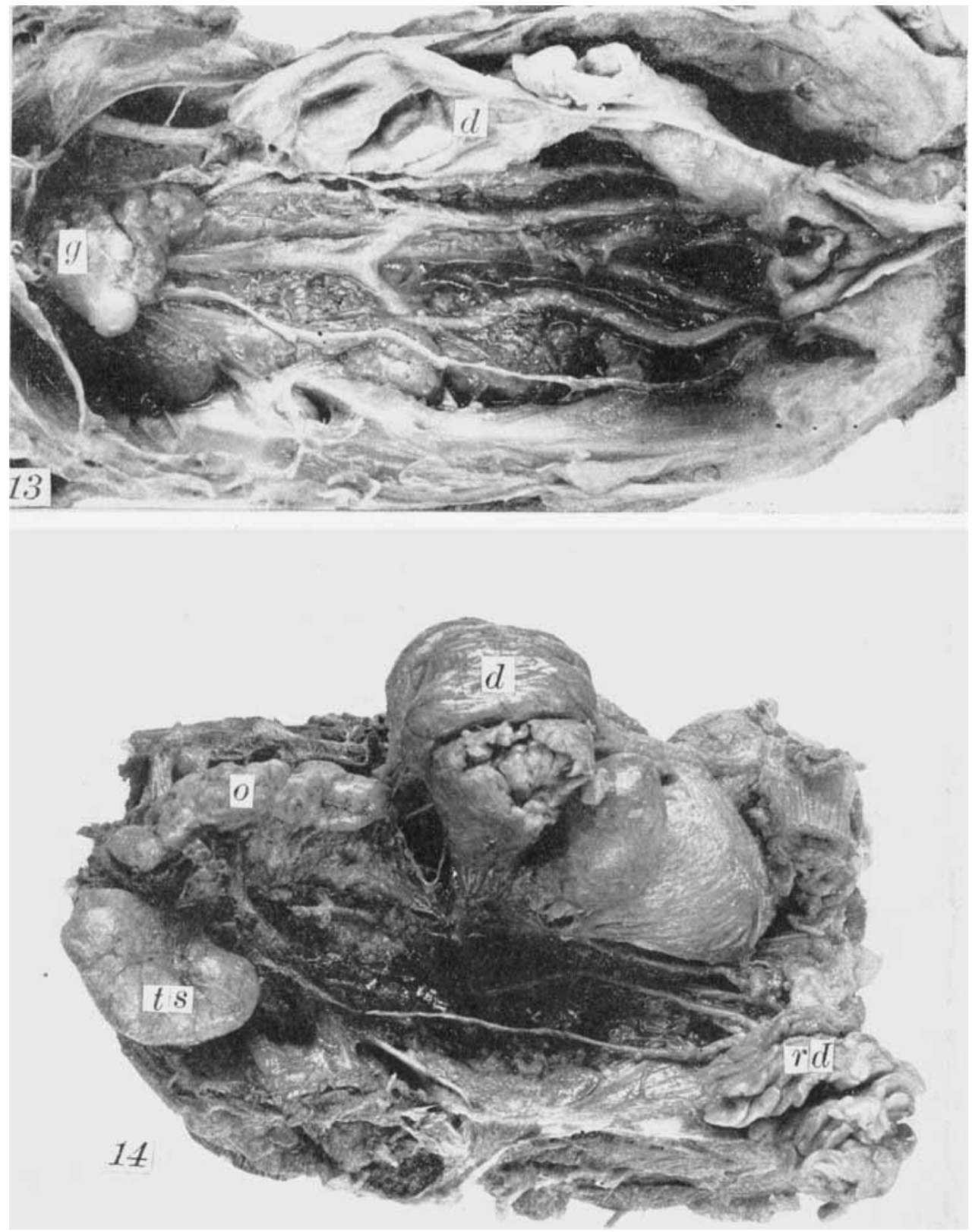
FLAHS

\section{EXPLANATION OF FIGURES}

15 Dissection of the urogenital system of Atwood's hermaphrodite bird. $d$, the small oviduet; $o$, the ovarian part of the left gonad; $t s$, the testicular part of the gonad.

16 Dissection of reproductive system of bird No.1349. $d$, the coiled oviduct; $g$, the reproductive organ.

17 Dissection of urogenital system of the Michigan hermaphrodite, No. 1616. $d$, the large oviduct; $g$, the large reproductive organ with a few oocytes showing on the surface. 
ALICE M. BORING AND RAYMOND PEARL
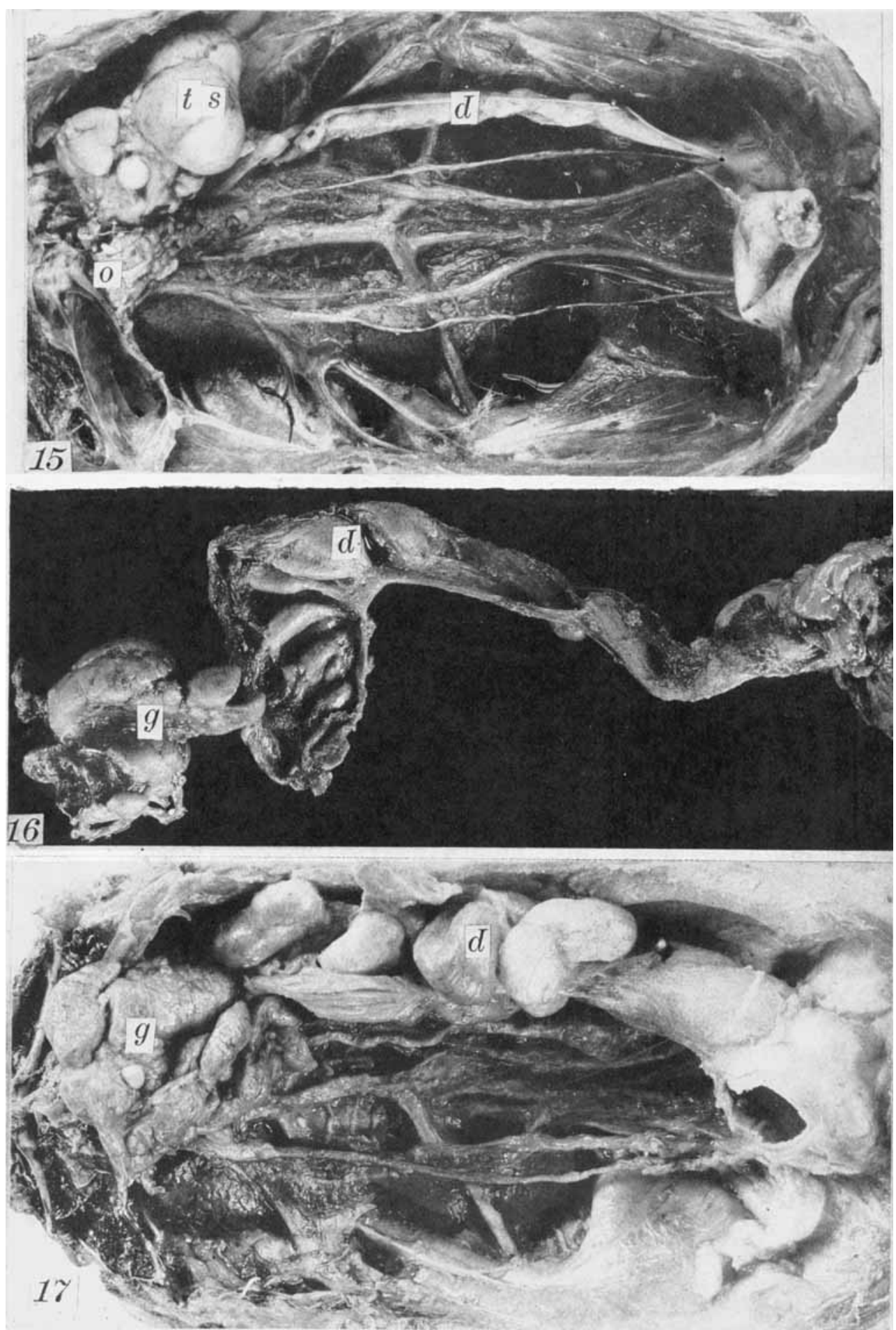


\section{PLATE 6}

EXPLANATION OF FIGURES

18 Section of ovary of 1429 showing oocytes $(\times 40)$.

19 Section of ovary of 1428 , showing stroma and mesonephric tubules ( $X$ 80). $t$, group of lutear cells.

20 Section of another part of gonad of 1428, showing mesonephric tubules and groups of lutear cells $(t) . \times 176$.

21 Section of ovary of 1427 , composed of nothing but stroma. (X 80$)$. 
SEX STUDIES. XI

PLATE 6

ALICE M. BORING AND RAYMOND PEARL

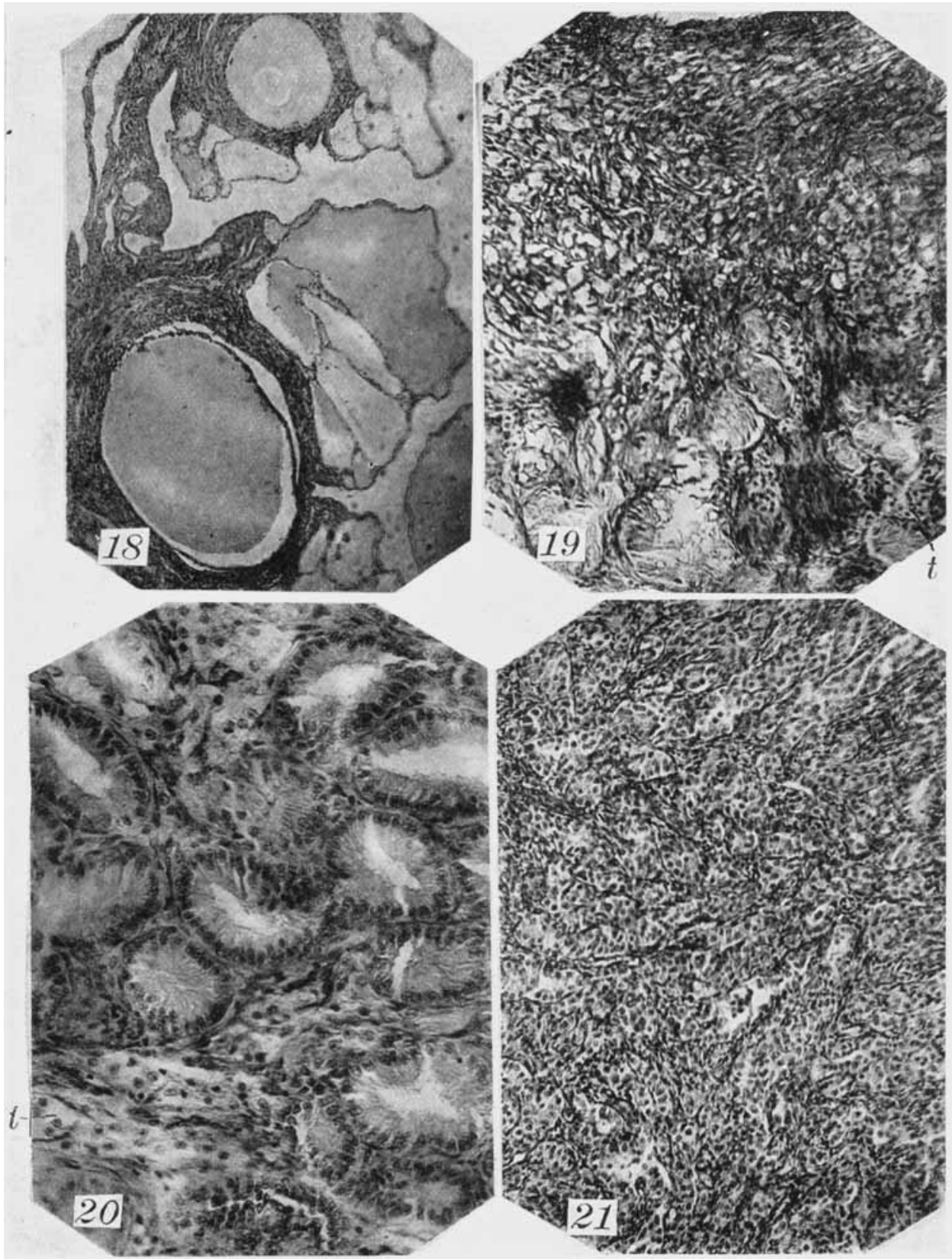




\section{PLATE 7}

\section{EXPLANATION OF FIGURES}

22 Section of ovary of 1425 , showing tubules and germinal epithelium ( $X$ $80)$.

23 Section of testis on right side of 1426 , showing seminal tubules $(\times 40)$.

24 Part of figure 23, showing two seminal tubules with sperm in center $(\times 176)$.

25 Section of ovary on left side of 1426 , showing stroma $(\times 80)$. 


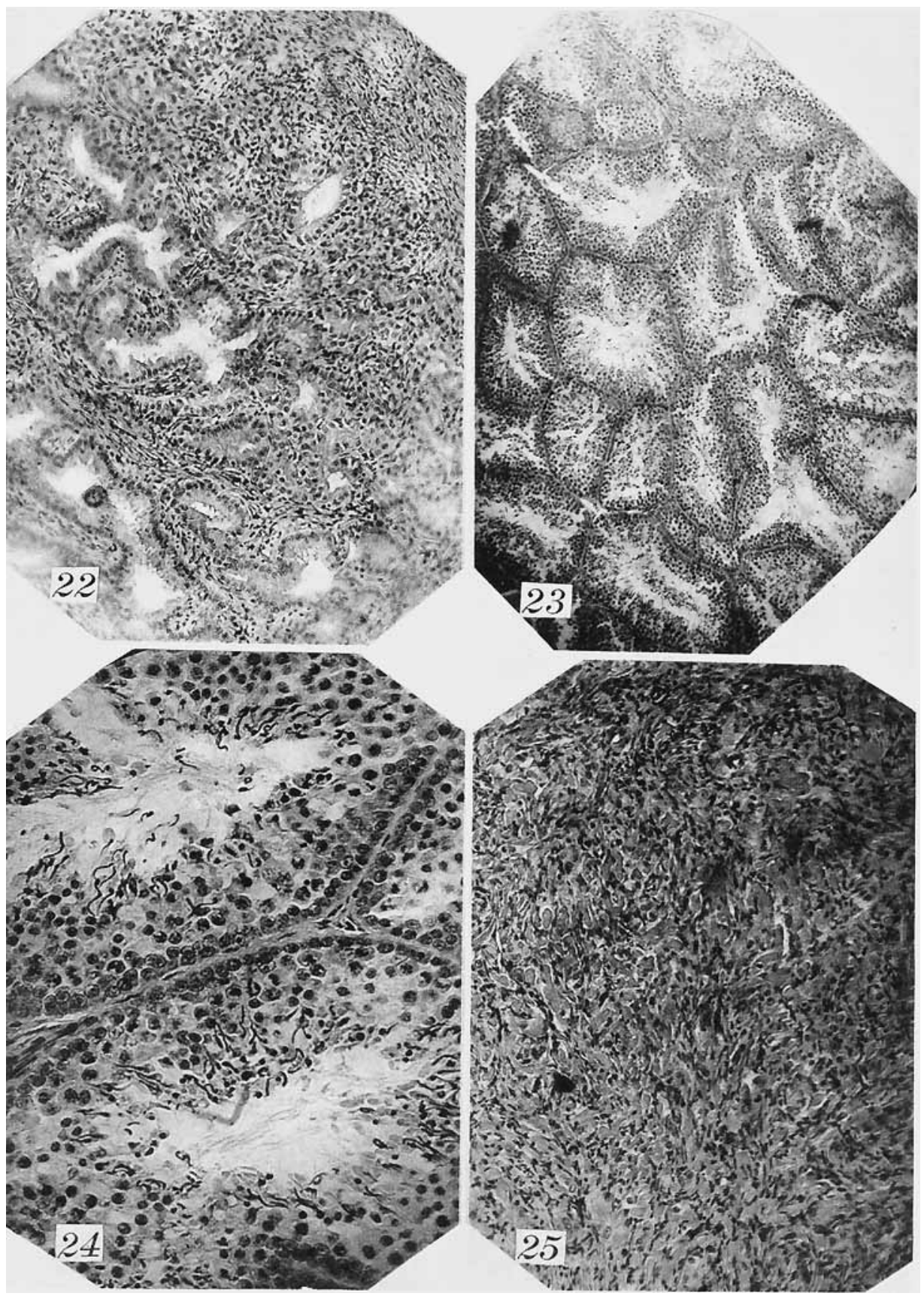




\section{PLATE 8}

\section{EXPLANATION OF TTGURES}

26 Section of ovarian part of gonad on left side of Atwood's hermaphrodite $(\times 40)$. ts, the testis tubules in the center of the organ.

27 Section of very small testis on right side of Atwood's hermaphrodite ( $X$ $80)$.

28 Section of testis part of gonad of $1349(\times 40)$.

29 Part of figure 28, showing seminal tubules with spermatids in center $(X$ 176). 

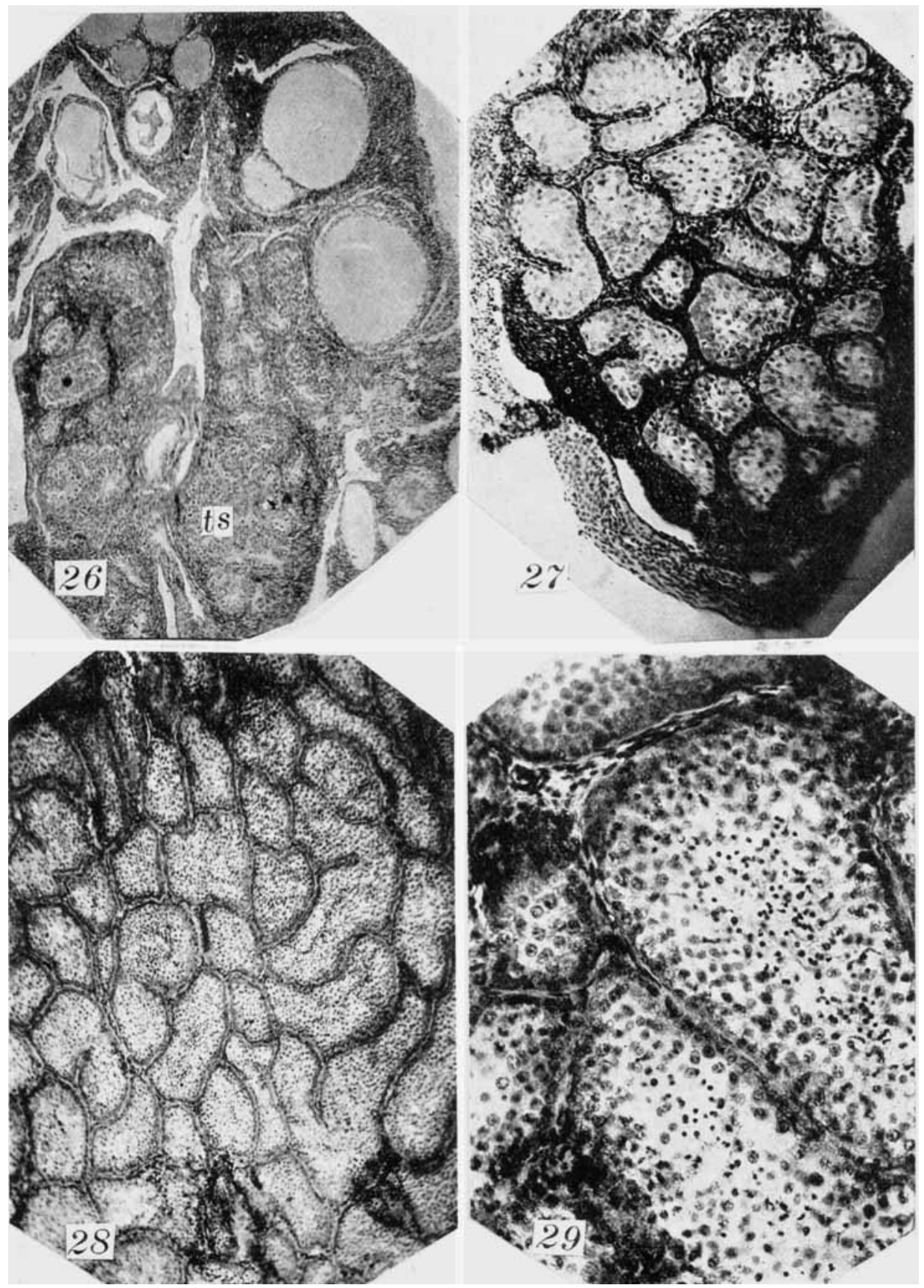
PLATE 9

EXPLANATION OF FIGURES

30 Section of an ovarian part of gonad of 1349 , showing stroma ( $\times 80)$.

31 Section of gonad of a guinea chicken hybrid, showing that organ is composed entirely of stroma $(\times 176)$.

32 Section of ovary of a just-hatched chick $(\times 40)$. $\quad c$, part composed of sex cords; $e$, germinal epithelium. $m$ is mesonephros. 


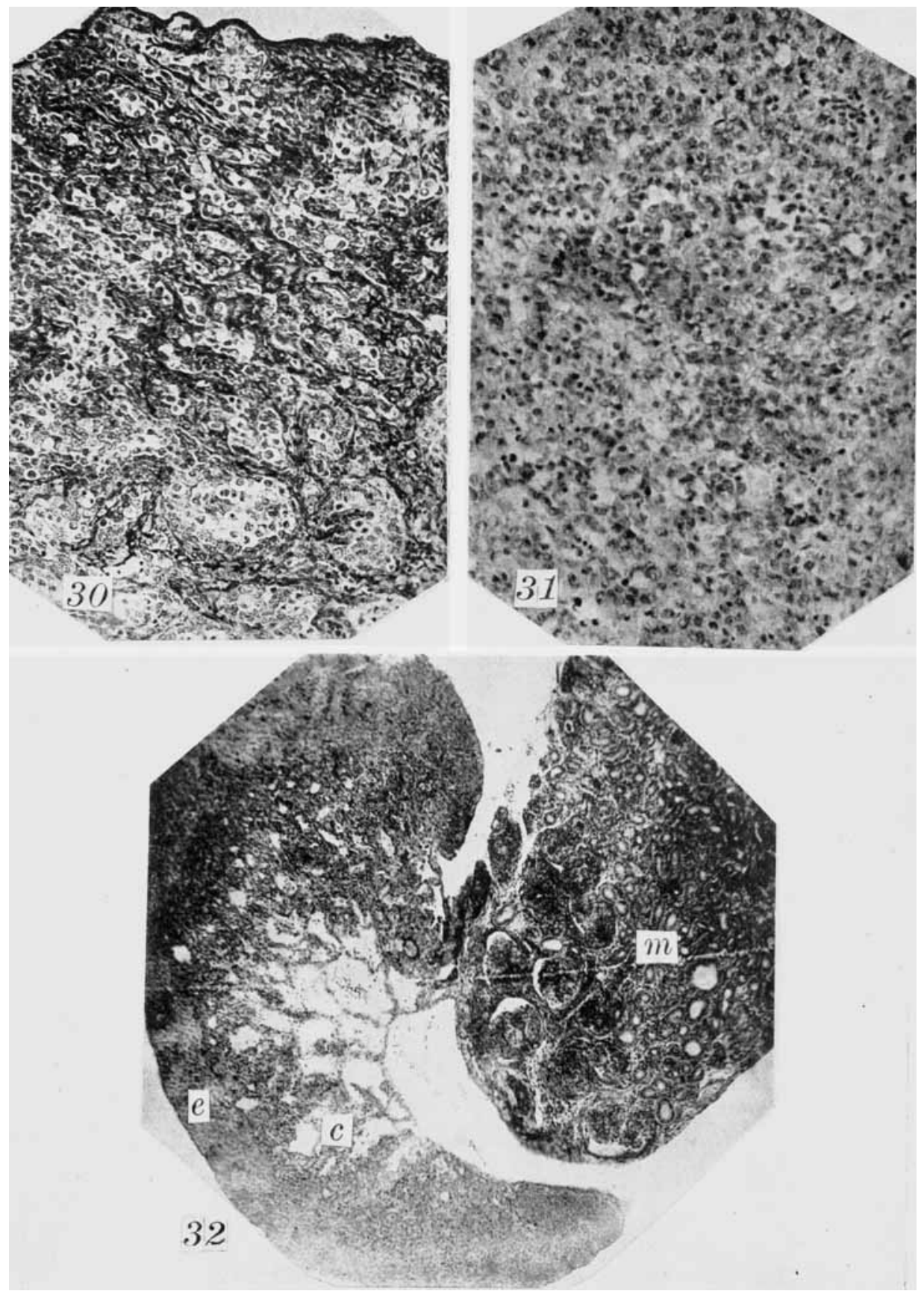

